\title{
Experience feedback on the management of an Ebola patient in a Guinea-based healthcare facility
}

\author{
B Ndoye ${ }^{1 *}$, OF Bangoura ${ }^{2}$, AO Diallo ${ }^{3}$ \\ From 3rd International Conference on Prevention and Infection Control (ICPIC 2015) \\ Geneva, Switzerland. 16-19 June 2015
}

\section{Introduction}

During the Ebola virus epidemic 2014-15, the case of a health facility where two doctors were contaminated was investigated to determine the reality of facts and circumstances that led to the case happening, in order to determine the causes and contributing factors to ultimately propose corrective actions.

\section{Objectives}

The aim is to raise awareness about the high risks of contamination in the facilities and to set up recommendations for all Guinean facilities.

\section{Methods}

A systematic analysis of the facts observed using the Orion method with phases of information collection and validation, followed by a variation and contributing factor analysis.

\section{Results}

The direct causes observed are mainly due to failure to comply with recommended good healthcare security practices, in particular standard and additional precautions during any healthcare. Contributing factors are mainly the lack of an infectious risk management program in general and the healthcare facility being unprepared for Ebola patient management in particular.

\section{Conclusion}

Suggested corrective actions include local administrative, organizational and technical measures to receive suspected cases and implement recommended healthcare precautions. They also relate to national measures to support healthcare facilities.

IICAN, Senegal

Full list of author information is available at the end of the article
This example is illustrative of the Guinean health system's current difficulties facing the epidemic for the component of infection control in healthcare facilities without international support. Substantive long term work will be necessary to effect changes in the organization of healthcare practices, but in all healthcare facilities, there is an urgent need to set up a secure system to handle the suspected cases they are supposed to receive any time during the epidemic.

\section{Disclosure of interest}

None declared.

\section{Authors' details}

${ }^{1}$ ICAN, Senegal. ${ }^{2}$ WHO, Guinea. ${ }^{3}$ Ministry of Health, Guinea.

Published: 16 June 2015

doi:10.1186/2047-2994-4-S1-P2

Cite this article as: Ndoye et al:. Experience feedback on the

management of an Ebola patient in a Guinea-based healthcare facility.

Antimicrobial Resistance and Infection Control 2015 4(Suppl 1):P2.

Submit your next manuscript to BioMed Central and take full advantage of:

- Convenient online submission

- Thorough peer review

- No space constraints or color figure charges

- Immediate publication on acceptance

- Inclusion in PubMed, CAS, Scopus and Google Scholar

- Research which is freely available for redistribution 